Federal Reserve Bank of Dallas

Globalization and Monetary Policy Institute

Working Paper No. 178

http://www.dallasfed.org/assets/documents/institute/wpapers/2014/0178.pdf

\title{
Credit Booms, Banking Crises, and the Current Account ${ }^{*}$
}

J. Scott Davis

Federal Reserve Bank of Dallas

Wesley Phoa

The Capital Group Companies
Adrienne Mack

Federal Reserve Bank of Dallas

Anne Vandenabeele

The Capital Group Companies

May 2014

Revised: October 2014

\begin{abstract}
A number of papers have shown that rapid growth in private sector credit is a strong predictor of a banking crisis. This paper will ask if credit growth is itself the cause of a crisis, or is it the combination of credit growth and external deficits? This paper estimates a probabilistic model to find the marginal effect of private sector credit growth on the probability of a banking crisis. The model contains an interaction term between credit growth and the level of the current account, so the marginal effect of private sector credit growth may itself be a function of the level of the current account. We find that the marginal effect of rising private sector debt levels depends on an economy's external position. When the current account is in balance, the marginal effect of an increase in debt is rather small. However, when the economy is running a sizable current account deficit, implying that any increase in the debt ratio is financed through foreign borrowing, this marginal effect is large.
\end{abstract}

JEL codes: E51; F32; F40

\footnotetext{
* J. Scott Davis, Research Department, Federal Reserve Bank of Dallas, 2200 N. Pearl Street, Dallas, TX 75201. 214-922-5124. scott.davis@dal.frb.org. Adrienne Mack, Research Department, Federal Reserve Bank of Dallas, 2200 N. Pearl Street, Dallas, TX 75201. 214-922-5793. adrienne.mack@dal.frb.org. Wesley Phoa, The Capital Group Companies, 11100 Santa Monica Blvd., Los Angeles, CA 90025. wesley_phoa@capgroup.com. Anne Vandenabeele, The Capital Group Companies, 11100 Santa Monica Blvd., Los Angeles, CA 90025. Anne_vandenabeele@capgroup.com. The views in this paper are those of the authors and do not necessarily reflect the views of the Capital Group, the Federal Reserve Bank of Dallas or the Federal Reserve System.
} 


\section{Introduction}

The experience of a number of countries during the recent Global Financial Crisis highlights the fact that rapid credit growth fueled by external borrowing is a recipe for a banking or financial crisis. This same combination of factors was at work during the East Asian crisis in the late 1990's and the Latin American crises of the 1980's. With these episodes in mind, McKinnon and Pill (1996), Magud, Reinhart and Vesperoni (2011), Kaminsky and Reinhart (1999), Barrell, Davis, Karim and Liadze (2010), Reinhart and Reinhart (2008), Reinhart and Rogoff (2011) discuss how capital inflow "bonanzas" can lead to a rapid expansion of credit which can then lead to a banking crisis.

A number of papers have shown that the root cause of a banking crisis is rapid credit growth. ${ }^{1}$ This raises an interesting question: is credit growth itself the cause of a crisis, or is it the combination of credit growth and external deficits? In other words, does the source of credit matter?

To answer this question, this paper will estimate the marginal effect of private sector credit growth on the probability of a banking crisis and estimate whether this marginal effect is itself a function of the current account. If a country is experiencing high credit growth and a current account deficit, that credit growth is being fueled from foreign borrowing. When a country is experiencing credit growth and a current account surplus, that credit growth is being fueled from domestic savings. So if the marginal effect of credit growth on the probability of a crisis is not a function of the current account then high, credit growth alone is a strong predictor of a crisis. If however this marginal effect is a function of the current account and is higher when the current account is in deficit, then it is the combination of high credit growth with foreign borrowing that is a predictor of a crisis.

Using a dataset that includes private sector credit growth for 14 advanced economies

\footnotetext{
${ }^{1}$ See e.g. Borio and Lowe (2002), Demirgüç-Kunt and Detragiache (1998), Demirgüç-Kunt and Detragiache (2005), Hume and Sentance (2009), Jordà, Schularick and Taylor (2011b), Jordà, Schularick and Taylor (2013), Kaminsky and Reinhart (1999), King (1994), Loayza and Ranciere (2005), Mendoza and Terrones (2008), Mendoza and Terrones (2012), Mian and Sufi (2009), Reinhart and Reinhart (2008), Jordà, Schularick and Taylor (2011a), McKinnon and Pill (1996), Arteta and Eichengreen (2002).
} 
from 1870-2008, Schularick and Taylor (2012) estimate the marginal effect of credit growth on the probability of a banking crisis. They show that the marginal effect is around 0.3. That is to say, a 1 percentage point increase in the credit-to-GDP ratio raises the probability of a banking crisis by 0.3 percentage points.

The role that large external imbalances and foreign borrowing play as precursors to banking crises is less understood. As mentioned earlier a number of papers discuss how capital inflow "bonanzas" can lead to a rapid expansion of credit which can then lead to a banking crisis, and Demirgüç-Kunt and Detragiache $(1998,2005)$ argue that the vulnerability to sudden capital outflows is a robust predictor of crises. Eichengreen and Rose (2004) argue that increases in interest rates in industrialized countries is a major factor driving banking crises in emerging market economies, but country-specific factors like external debt burdens and the current account are less important. Chinn and Kletzer (1999) construct a model where agency problems arising from government guarantees on bank deposits lead naturally to a scenario where capital inflows lead to excess credit growth followed by a banking crisis.

Copelovitch and Singer (2012) argue that the link between current account deficits and the incidence of a banking crisis depends on certain institutional characteristics, namely, whether financial markets tend to be "market-based" or "bank-based". Jordà et al. (2011a) estimate a logit model to calculate how factors like credit growth and the change in the current account affect the probability of a banking crisis. They find that the change in the current account was a robust predictor of crises in pre-World War II data, but the effect is insignificant in the post-Breton Woods period. Aizenman and Noy (2013) show that rapid credit growth is a robust predictor of crises, and that capital account openness lowers the probability of a crisis in middle-income countries.

This paper performs a similar exercise as that performed in Jordà et al. (2011a) and Schularick and Taylor (2012) using a different dataset. The goal will be the same, to measure the marginal effect of an increase in credit growth on the probability of a banking crisis. However, by considering the interaction between credit growth and the level of the current 
account, we can calculate how the marginal effect of credit growth on the probability of a banking crisis is itself a function of the level of the current account.

We find that the marginal effect depends strongly on the current account. For a country with a balanced current account, a 1 percentage point increase in credit growth increases the probability of a crisis by about 0.1 percentage points. For a country with a current account deficit of $10 \%$ of GDP (the size of the current account deficit in many countries of the Eurozone periphery prior to the recent crisis), a 1 percentage point increase in credit growth increases the probability of a crisis by about 0.5 percentage points.

The rest of this paper is organized as follows. Section 2 contrasts the examples of Norway, Finland and Sweden with the countries of the Eurozone periphery on the eve of the recent crisis. Both the Nordic and the periphery countries had seen a rapid growth in private sector credit in the years leading up to the crisis; in the years prior to 2008, private sector credit growth in Sweden was actually larger than in nearly all countries of the Eurozone periphery. However, unlike the Eurozone periphery, the Nordic countries ran large current account surpluses. The fact that the Nordic countries did not experience a banking crisis while those in the Eurozone periphery did suggests that credit growth on its own does not cause a crisis, but the combination of credit growth with large external borrowing can be a potent mix. Section 3 presents the econometric models and the data that we will use to estimate the marginal effect of credit growth on the probability of a crisis. The results from these estimations are presented in section 4. First we will show how the marginal effect of credit growth can vary dramatically depending on a country's external position. Then, returning to the examples of the Nordic countries and those of the Eurozone periphery on the eve of the recent crisis, we will discuss how taking this into account can improve the ability of a model to distinguish between a benign credit boom fueled by domestic lending and a dangerous credit boom fueled by external borrowing. The results from various robustness

tests are presented in section 5 . Finally section 6 will conclude. 


\section{The Nordics vs. the Periphery}

Throughout history a number of countries, most recently countries in the "periphery" of the Eurozone, have suffered severe banking crises. The circumstances under which this most recent crisis occurred can be illustrated, and perhaps further illuminated, by taking a closer look at private sector credit growth and current account dynamics in the years leading to the crises.

A combination of external and domestic factors pushed several Eurozone countries into a financial crisis, culminating in severe market and banking sector stress most notably between 2008 and 2012. Starting in the 1990s, progress towards monetary union caused Eurozone interest rates to converge and eventually spurred significant asset price appreciation and credit booms in several peripheral countries. For example, house prices appreciated by $46 \%$ in Spain and 45\% in Ireland between 2003 and 2008. The nonfinancial private sector creditto-GDP ratio grew by 72 percentage points in the Eurozone periphery in the 5 years between 2003 and 2008, with Ireland (145pp) and Italy (32pp) at the high- and low-end of the group. The global financial crisis exposed this excess credit growth when it became more difficult to roll over these large debt burdens.

At that point, it also became obvious that the inability of peripheral countries to raise interest rates during the boom, due to the single currency and single monetary policy regime, had worsened imbalances including widening current account deficits. The average current account deficit for peripheral countries was $9 \%$ of GDP in 2008. This largely stemmed from overvalued exchange rates for these economies, as the combination of wage rigidities and fixed exchange rates led to persistent declines in competitiveness. In 2008, Greece, Portugal, Ireland, and Spain each suffered banking crises. In the spring of 2010, Greece was granted international assistance to address its unsustainable public debt burden and was followed by Ireland and Portugal.

The experience of peripheral economies, characterized by credit booms, current account deficits, and ultimately banking crises, is interesting to contrast with the Nordic countries 
of Norway, Sweden, and Finland. Over the five years to 2008, the Nordic countries also saw significant growth in the nonfinancial private credit-to-GDP ratio (39pp in Norway, 38pp in Finland, and 74pp in Sweden) but, unlike the peripheral economies, the Nordic countries did not suffer a banking crisis.

One of the most important factors to explain the fact that the countries of the Eurozone periphery suffered a banking crisis in 2008 but the Nordic countries, with similar levels of credit growth, did not, is the fact that the Nordic countries maintained a strong current account surpluses (close to $16 \%$ of GDP for Norway, $3 \%$ for Finland, and $9 \%$ for Sweden). ${ }^{2}$ This current account surplus indicates that the Nordic did not rely on external funding to fund this credit boom as in the Eurozone periphery. As will be seen in the coming sections, a credit boom accompanied by a current account surplus still increases the probability of a banking crisis, but the effect is pretty small. Sweden saw growth in the private sector creditto-GDP ratio of 74pp between 2003 and 2008, but the marginal effect of each 1pp increase in credit growth on the probability of a crisis was only $0.017 \mathrm{pp}$, and as we shall see later, the probabilistic model in this paper estimates that the probability of a banking crisis in Sweden in 2008 was $6 \%$. Meanwhile, Spain saw growth in the private sector credit-to-GDP ratio of 79pp between 2003 and 2008. The marginal effect of each 1pp increase in credit growth on the probability of a crisis was $0.518 \mathrm{pp}$, and the model predicts that the probability of a crisis in Spain in 2008 was $71 \% .^{3}$

\section{Econometric Methodology and Data}

To formally test the effect of a country's recent credit growth and current account on the probability of a banking crisis, we estimate a probabilistic model of a banking crisis in country $i$ in year $t$ using data from an unbalanced panel of 35 countries and annual data potentially

\footnotetext{
${ }^{2}$ In addition to credit booms, the Nordic countries also saw comparable levels of house price appreciation. Between 2003 and 2008, house prices rose by 33\% in Finland, 45\% in Norway, and $49 \%$ in Sweden. (Mack and Martínez-García 2011)

${ }^{3}$ In the data used in this paper, the unconditional probability of a banking crisis in a given country-year is $4.5 \%$.
} 
from 1970-2010.

The model to regress the incidence of a banking crisis in country $i$ in year $t$ on recent private sector credit growth, the current account balance, and other control variables can take two forms:

$$
\begin{aligned}
& \text { OLS Linear Probability: } p_{i t}=\begin{array}{r}
\alpha+\beta_{1} \Delta C_{i t}+\beta_{2} C A_{i t-1}+\beta_{3} \Delta C_{i t} \times C A_{i t-1} \\
+\beta_{4} \mathbf{I}_{i t}^{C A<0} \times \Delta C_{i t} \times C A_{i t-1}+\boldsymbol{\beta} \mathbf{X}_{i t}+\varepsilon_{i t}
\end{array} \\
& \qquad \begin{array}{r}
\delta+\gamma_{1} \Delta C_{i t}+\gamma_{2} C A_{i t-1}+\gamma_{3} \Delta C_{i t} \times C A_{i t-1} \\
+\gamma_{4} \mathbf{I}_{i t}^{C A<0} \times \Delta C_{i t} \times C A_{i t-1}+\gamma \mathbf{X}_{i t}+\varepsilon_{i t}
\end{array}
\end{aligned}
$$

where $\operatorname{logit}\left(p_{i t}\right)=\ln \left(p_{i t} /\left(1-p_{i t}\right)\right), \Delta C_{i t}$ is the growth in the private sector credit-to-GDP ratio in country $i$ over the 5 years prior to year $t, C A_{i t-1}$ is the ratio of the current account balance to GDP in country $i$ in year $t-1, \mathbf{I}_{i t}^{C A<0}$ is an indicator variable that takes a value of 1 if country $i$ is running a current account deficit in year $t-1$ and 0 otherwise, and $\mathbf{X}_{i t}$ is a vector that includes the output gap, the inflation rate, and an indicator variable denoting whether country $i$ has a fixed or floating exchange rate in year $t$.

The estimated coefficients from either this linear probability model or logit model can then be used to find the marginal effect of an increase in the growth of private sector credit on the probability of a banking crisis. In the linear probability model, the marginal effect of a 1 percentage point increase in the growth of the private debt-to-GDP ratio on the probability of a banking crisis in a country with a current account surplus of $5 \%$ of GDP is $\beta_{1}+0.05 \beta_{3}$. The same marginal effect in a country with a current account deficit of $5 \%$ of $\mathrm{GDP}$ is $\beta_{1}-0.05\left(\beta_{3}+\beta_{4}\right)$.

If we impose that there is no interaction between credit growth and the current account $\left(\beta_{3}=\beta_{4}=0\right)$ than in the linear probability model, the marginal effect of a 1 percentage point increase in the growth of the private debt-to-GDP ratio on the probability of a banking crisis is $\beta_{1}$. If instead we allow for an interaction between credit growth and the current 
account, but impose that this interaction is the same regardless of whether the current account is in surplus or deficit $\left(\beta_{4}=0\right)$, then in the linear probability model, the marginal effect of a 1 percentage point increase in the growth of the private debt-to-GDP ratio on the probability of a banking crisis in a country with a current account surplus of $5 \%$ of GDP is $\beta_{1}+0.05 \beta_{3}$. The same marginal effect in a country with a current account deficit of $5 \%$ of GDP is $\beta_{1}-0.05 \beta_{3}$.

When we do not allow for an interaction between credit growth and the current account $\left(\beta_{3}=\beta_{4}=0\right)$, the marginal effect of an increase in credit growth on the probability of a crisis does not depend on whether that credit growth is financed abroad or at home. When we do allow for this interaction, but impose that this interaction is the same regardless of whether the current account is in surplus or deficit $\left(\beta_{4}=0\right)$, the marginal effect of an increase in credit growth on the probability of a crisis depends on the current account, but moving from a current account surplus of $10 \%$ to a current account surplus of $2 \%$ has the same impact on this marginal effect as moving from a current account deficit of $2 \%$ to a current account deficit of $10 \%$. If instead the interaction between credit growth and the current account depends on whether the current account is in deficit or surplus then the marginal effect of credit growth and the current account depends on whether or not a country has a current account deficit. For instance if $\beta_{3} \approx 0$ but $\beta_{4}<<0$ then moving from a current account surplus of $10 \%$ to a current account surplus of $2 \%$ has no impact on the marginal effect of credit growth on the probability of a crisis, since the credit growth is still financed domestically, but moving from a current account deficit of $2 \%$ to a current account deficit of $10 \%$ has a large impact on the marginal effect of an increase in credit growth on the probability of a crisis, since with a current account deficit of $10 \%$ of GDP, the country is highly dependent on foreign borrowing.

To calculate the marginal effects in the nonlinear logit model we follow Ai and Norton (2003), who describe how to calculate marginal effects in a nonlinear model with an interaction term between two independent variables. Consider that the specification for the logit 
model in (1) can be re-written as:

$$
P\left(\text { Crisis }=1 ; \Delta C_{i t}, C A_{i t}, \mathbf{X}_{i t}\right)=F\left(\begin{array}{c}
\delta+\gamma_{1} \Delta C_{i t}+\gamma_{2} C A_{i t-1}+\gamma_{3} \Delta C_{i t} \times C A_{i t-1} \\
+\gamma_{4} \mathbf{I}_{i t}^{C A<0} \times \Delta C_{i t} \times C A_{i t-1}+\gamma \mathbf{X}_{i t}+\varepsilon_{i t}
\end{array}\right)
$$

where $F(y)=\frac{e^{y}}{1+e^{y}}$. Thus the marginal effect of the growth in private sector credit on the probability of a banking crisis is:

$$
\frac{\partial P(\text { Crisis }=1)}{\partial \Delta C}=F^{\prime}(y)\left(\gamma_{1}+\left(\gamma_{3}+\gamma_{4} \mathbf{I}_{i t}^{C A<0}\right) C A_{i t-1}\right)
$$

The marginal effect for a country with a current account-to-GDP ratio of $d C A$ is:

$$
\frac{\partial P(\text { Bank }=1)}{\partial \Delta C}+\frac{\partial^{2} P(\text { Bank }=1)}{\partial \Delta C \partial C A}(d C A)
$$

which can be written as:

$$
\begin{aligned}
& F^{\prime}(y)\left(\gamma_{1}+\left(\gamma_{3}+\gamma_{4} \mathbf{I}_{i t}^{C A<0}\right) C A+\left(\gamma_{3}+\gamma_{4} \mathbf{I}_{i t}^{C A<0}\right) d C A\right) \\
& +F^{\prime \prime}(y)\left(\gamma_{1}+\left(\gamma_{3}+\gamma_{4} \mathbf{I}_{i t}^{C A<0}\right) C A\right)\left(\gamma_{2}+\left(\gamma_{3}+\gamma_{4} \mathbf{I}_{i t}^{C A<0}\right) \Delta C_{i t}\right)(d C A)
\end{aligned}
$$

In an alternative specification, instead of considering the effect of the level of the current account-to-GDP ratio in year $t-1, C A_{i t-1}$, we will consider the change in this ratio from year $t-2$ to $t-1, \Delta C A_{i t-1}=C A_{t-1}-C A_{t-2}$. While these two specifications look very similar, the interpretation is different. Jordà et al. (2011a) consider the latter, where the firstdifference of the current account is included in the probability model. In this specification, a negative and significant estimate of $\gamma_{2}$ would imply that a rapid deterioration of the current account is a harbinger of a banking crisis. Jordà et al. (2011a) find that this is the case, but it is more prevalent in the early part of their sample period. Similarly a negative and 
significant estimate of $\gamma_{3}$ or $\gamma_{4}$ would imply that rapid credit growth is more dangerous when accompanied by a rapid deterioration in the current account. Jordà et al. (2011a) find that the coefficient on the interaction term is not significant, so credit growth is a harbinger of a crisis and a rapid deterioration of the current account is a harbinger of a crisis, but after controlling for each effect separately, the interaction is not significant. Intuitively this means that rapid credit growth is not more likely to lead to a crisis just because it is accompanied by current account deterioration. Just because the current account is deteriorating, we cannot tell whether the credit boom is being financed from domestic savings or foreign borrowing, since the current account deterioration from $C A_{i t-2}=5$ to $C A_{i t-1}=0$ is the same deterioration as from $C A_{i t-2}=0$ to $C A_{i t-1}=-5$. Although in the first case the country is still financing its credit growth from domestic savings and in the second it is relying on foreign borrowing.

\subsection{Variables and Data}

The dependent variable in all of the above regressions, $p_{i t}$, is an indicator variable denoting if country $i$ was experiencing a banking crisis in year $t$. This is described in Reinhart and Reinhart (2008) and Reinhart and Rogoff (2009). It is available for a large number of countries over a 200 year period, but due to data limitations in our main independent variable, the growth in the credit-to-GDP ratio, we restrict our analysis to an unbalanced panel of 35 countries, potentially beginning in 1975. The full list of countries and the years that they are included in the study is found in the appendix. We also confirm that these results are robust to an alternative banking crisis indicator variables developed in Laeven and Valencia (2013).

Since many banking crises unfold over a number of years, there is the question of what

to do with observations after the initial crisis year, since the macroeconomic explanatory variables that would be used to predict a crisis in the later years of a crisis would themselves be affected by the early years of the crisis. We follow the convention in the literature, as 
described by Demirgüç-Kunt and Detragiache (2005) and simply exclude the crisis years after year 1 from the sample.

The main dependent variable, $\Delta C_{i t}$, represents the excess growth in the private or public sector debt-to-GDP ratio between year $t-5$ and year $t$. The stock of private sector credit used to construct $\Delta C_{i t}$ is taken from the BIS database of credit to the private nonfinancial sector.

We define the excess credit growth as the growth in the private sector debt-to-GDP ratio over a 5 year period in excess of the trend growth in that ratio:

$$
\Delta C_{i t}=\Delta \text { Credit }_{i t}-\Delta C r \tilde{e} \text { itt }_{i t}
$$

where $\Delta$ Credit ${ }_{i t}$ is the actual growth in the private sector debt-to-GDP ratio between year $t-5$ and year $t$, and $\Delta C r e \tilde{e} i_{i t}$ is the trend growth in this ratio over this period. We will define this trend growth in a number of ways and show that the results are not sensitive to our particular measure of trend. In the benchmark specification, we define trend credit growth as that which can be explained by growth in per-capita GDP and the usual process of financial deepening:

$$
\Delta C r \tilde{e} d i t_{i t}=\theta \Delta g d p_{i t}
$$

where $\Delta g d p_{i t}$ is the change in per-capita GDP in country $i$ between year $t-5$ and year $t$, and $\theta$ is estimated from a panel data model. For the 35 countries in our model over the period 1970-2010, $\theta$ is the average elasticity of the private sector credit-to-GDP ratio with respect to changes in per-capita income. Our point estimate for this elasticity is about 0.84 and the $95 \%$ confidence interval lies between 0.82 and $0.86 .^{4}$

\footnotetext{
${ }^{4}$ The relationship between financial deepening and economic growth, studied empirically as early as Goldschmidt (1933), was firmly established in cross-country studies beginning with King and Levine (1993). It has been further confirmed by studies focusing on the industry level, e.g. Rajan and Zingales (1998), and the regional level, e.g. Jayaratne and Strahan (1996). For further discussion see the first chapter of Calomiris and Haber (2014).
} 
For robustness we will also define trend credit growth, $\Delta C r e \tilde{d} i t_{i t}$, as the change between year $t-5$ and year $t$ of the HP filtered trend of the private sector credit-to-GDP ratio or the linear trend in the credit-to-GDP ratio. Finally, we will ignore the trend component and instead define the variable $\Delta C_{i t}$ in our linear probability and logit models as simply the actual growth in the credit-to-GDP ratio over a 5 year period.

Other variables included in the regressions include the ratio of the current account to GDP, $C A_{i t}$, the $\log$ deviation of GDP from its HP trend, $O G_{t}$, the year-over-year percent change in consumer price index, $\pi_{t}$, and an indicator variable denoting whether a country has a pegged currency or a crawling peg (1) or a freely floating currency or a managed float (0) as defined by Ilzetzki, Reinhart and Reinhart (2008).

The means and standard deviations of the variables in the model are presented in table 1. The table shows that the unconditional probability of a banking crisis in any given country in any given year in our sample is approximately $4.5 \%$, and the average growth in the credit-to-GDP ratio over a 5 year period is nearly 13 percentage points.

Furthermore, the unconditional correlations between the variables in the model are presented in table 2. This table shows that the correlation between excess credit growth and the incidence of a banking crisis is about 0.1-0.2. The current account is slightly negatively correlated with the incidence of a banking crisis, and the correlation between the current account and credit growth shows that periods of high excess private sector credit growth tend to be accompanied by current account deficits.

\section{Results}

The results from the regression specifications in (1) are presented in table 3 . The table presents the results using the primary measure of excess credit growth where the trend level of credit growth is defined as that which can be explained by growth in per capita GDP.

The table presents the results from both the logit model and the OLS linear probability 
model. The table shows that when the interaction between credit growth and the current account is not included in the regression, credit growth has a positive and significant effect on the probability of a banking crisis. The marginal effects estimates show that a one percentage point increase in credit growth increases the probability of a banking crisis by about 0.13 percentage points. Furthermore, the output gap has a negative and significant effect on the probability of a banking crisis. A one percentage point increase in the output gap reduces the probability of a banking crisis by about 1.5 percentage points.

On its own, the current account has a negative impact on the probability of a crisis, although this is not robust to the different regression specifications. The second and fifth columns of the table show that the interaction between credit growth and the current account has a negative and significant effect. This implies that credit growth has a greater effect on the probability of a crisis when a country is running a current account deficit. The table reports the marginal effects of credit growth for a country with a balanced current account, one with a current account deficit of $5 \%$, and one with a current account surplus of $5 \%$. For a country with a balanced current account, the marginal effect of credit growth on the probability of a crisis is around 0.16. For a country with a current account deficit of $5 \%$, a one percentage point increase in the credit-to-GDP ratio increases the probability of a banking crisis by around 0.27 percentage points. For a country with a current account surplus of $5 \%$, the same increase in credit growth raises the probability of a crisis by 0.05 percentage points. Wald-tests confirm that we can reject the hypothesis that the marginal effect of credit growth on the probability of a crisis is does not depend on whether a country is running a current account surplus or deficit. This confirms the results in Reinhart and Reinhart (2008) who find that a capital flow "bonanza" leads to a significant increase in the probability of a banking crisis.

When we include an interaction term between credit growth and the current account, but do not distinguish between a current account surplus or deficit, the model shows that extreme values of the current account can affect the marginal effect of credit growth, but for 
most countries with a small current account deficit or surplus, the marginal effect of credit growth is around 0.15 in both models. However this changes when we include an interaction term between the current account and credit growth, but allow this interaction to distinguish between a current account deficit or surplus. These results are found in the third and sixth columns of table 3 . Now the marginal effect for a country with a balanced current account is only around 0.08 . For a country with a current account surplus of $5 \%$ of GDP, the marginal effect of credit growth is around 0.05. However, for a country with a current account deficit of $5 \%$, the marginal effect is 0.30 .

Wald-tests confirm that there is a statistically significant difference between the marginal effect for a country with a current account deficit and that with a balanced current account, but the difference between the marginal effects for a country with a current account surplus and that with a balanced current account is not significantly different than zero.

The marginal effect of an increase in credit growth on the probability of a banking crisis as a function of the current account in each of the three model is presented in figure 1 . The figure plots the estimated marginal effect of credit growth and $90 \%$ confidence bands as a function of the current account in the three specifications of the linear probability model. In the first model, the one without an interaction term between credit growth and the current account, the marginal effect is constant at around 0.13. In the second version of the model, with an interaction but one that does not distinguish between a current account deficit or surplus, the marginal effect is a downward sloping line with an intercept of around 0.16. In the version of the model where the interaction depends on whether the county has a positive or negative current account, the marginal effect is around 0.08 for a country with a balanced current account and falls slightly as the current account increases, but when the current account is negative, the marginal effect is quickly increasing in the size of the current account deficit. For a country with a current account deficit of around 10\% of GDP, a one percentage point increase in credit growth leads to greater than a 0.5 percentage point increase in the probability of a banking crisis. 
The results from the regression where the current account term is not the level of the current account-to-GDP ratio in year $t-1$ but rather the difference in this ratio from years $t-2$ to $t-1$ is presented in table 4 . The interaction between credit growth and the change in the current account is not significant. This confirms the results in Jordà et al. (2011a) who also find that the interaction between credit growth and the change in the current account has no added power as a predictor of a banking crisis. The table also shows that the coefficient on the change in the current account is not significant. This again confirms the results in Jordà et al. (2011a), who find that the coefficient of the change in the current account is negative and significant in the pre-World War II part of their time series, indicating that the rapid deterioration in the current account was a harbinger of a crisis. However, they find that the coefficient on the change in the current account is not significant in the post-World War II data.

\subsection{The Receiver Operating Characteristic Curve}

A way to test the predictive ability of the probabilistic model specifications (1) is to calculate the receiver operating characteristic curve (ROC). The ROC plots the true positive rate against the false positive rate of either the logit or linear probability model for different values of the critical value $c$, above which we predict a crisis and below which we do not. If we vary $c$ from zero to one and calculate and plot the false and true positive rates for each value of $c$ then the resulting ROC curve is plotted in figure 2 .

The figure plots the ROC curves for each of the tree versions of the model. When $c \approx 0$, the models predict a banking crisis in every observation, so both the false positive rate and the true positive rate are 100\%. As $c$ increases, both rates fall. The model has no predictive ability if the ROC curve lies along the 45-degree line; it's predictive ability is perfect if the ROC curve resembles an upside-down "L" and passes through the point where the true positive rate is $100 \%$ and the false positive rate is $0 \%$. The figure shows that the ROC curve from the model with the interaction term (the red dashed line) generally lies to the left of 
that from the model with no interaction term, implying that including this term improves the predictive ability of the model.

The last row of table 3 presents the area under the ROC curve for each model. If the area under the ROC curve is 0.5 then the model has no predictive ability and it has perfect predictive ability when the area is equal to one. The table shows that the both the logit and linear probability versions of the model, the area under the ROC curve is around $0.74-0.76$. This is close to the value found by Schularick and Taylor (2012) in their estimation based on a sample of developed countries over a nearly 140 year period. When the interaction term is not included in the model, the area under the ROC curve is around $0.74 .^{5}$

\subsection{Back to the Nordics and the Periphery}

This paper began by contrasting the experience of the Eurozone periphery in 2008 with that in Norway, Finland, and Sweden. As mentioned earlier, both the Eurozone periphery as well as the Nordic countries saw huge credit booms in the 5 years leading up to 2008, but unlike the Eurozone periphery, which ran a large current account deficit, the Nordic countries ran current account surpluses.

The excess credit growth in the 5 years leading up to 2008, the current account, and the probabilities of a banking crisis predicted by the regression specifications in (1) are presented in table 5. The table shows that all of these countries, Portugal, Spain, Ireland, Greece, Hungary, Finland, Norway, and Sweden, had a large increase in the private sector credit-to-GDP ratio between 2003 and 2008. Of course the credit boom in Portugal, Spain, Ireland, Greece, and Hungary between 2003 and 2008 is well known, but over this same period credit growth in Sweden was actually greater than that in Portugal and Greece and was nearly identical to that in Spain and Hungary. The table also reports that in 2008, the Nordic countries each had current account surpluses. Meanwhile Portugal, Spain, Ireland,

\footnotetext{
${ }^{5}$ The models used to calculate the ROC curves do not include country or time fixed effects. Given the tendency of financial crises to occur in many countries at the same time, the inclusion of time fixed effect significantly raises the in-sample fit of the model, and the area under the ROC curve rises to as much as 0.9 when time fixed effects are included.
} 
Greece, and Hungary were each running sizable current account deficits that ranged from $-6 \%$ of GDP (Ireland) to $-15 \%$ of GDP (Greece).

The table reports the probability of a banking crisis implied by the different specifications of the model. $P_{1}$ (Crisis) is the probability of a banking crisis implied by either the logit model without the interaction term between credit growth and the current account, $P_{2}$ (Crisis) is the probability of a banking crisis in the model that includes this interaction term, and $P_{3}($ Crisis $)$ is the probability of a banking crisis when the interaction term can distinguish between a current account deficit and surplus. Based on its sizable credit boom between 2003 and 2008, the model without the interaction term predicts that Sweden had a one-in-six chance of experiencing a banking crisis in 2008. In Spain this probability was about $50 \%$. However, when the fact that this credit boom was financed domestically in the case of the Nordic countries but financed by foreign borrowing in the case of Portugal, Spain, Ireland, Greece, and Hungary, these probabilities change. In the model with the interaction term between credit growth and the current account, the chance of a banking crisis in Sweden falls to one-in-twenty but the probability of a crisis in Spain rises to $70 \%$.

\section{Sensitivity Analysis}

To confirm the robustness of this paper's key result, we will first examine the estimation results from the same regressions using the alternative measures of excess credit growth. The estimation results using the other three measures of excess credit growth are presented in tables 6-8. As the tables show, the fact that the interaction term between credit growth and the current account is significant continues to hold, and thus the result that the marginal effect of credit growth on the probability of a crisis is robust to a number of different measures of excess credit growth.

Next we consider the results using an alternative banking crisis indicator in Laeven and Valencia (2013). This banking crisis indicator is more conservative, and the unconditional 
probability of a banking crisis in a given country-year is only $2.8 \%$ using the Laeven and Valencia indicator, as opposed to $4.5 \%$ using the Reinhart and Rogoff indicator. The results using this alternative banking crisis indicator as the dependent variable are presented in table 9. The fact that the marginal effect of credit growth on the probability of a crisis is a function of the current account continues to hold in the linear probability specification, although this result is no longer statistically significant under the logit specification.

We then split the sample of 35 countries into 2 subsets of 20 developed or 15 emerging market countries. The results from the benchmark specification using only a subset of 20 developed countries is presented in table 10, and the results from the subsample of 15 emerging markets are presented in table 11. The tables show that this result that the marginal effect of credit growth is a function of the current account continues to hold across the two country subgroups, so this finding is not simply a function of certain developed economies or certain emerging market economies.

Finally we examine the results when the current account variable used in the regression is not the current account from one year, $C A_{t-1}$, but is the average current account over the past five years, $\overline{C A}$. These results are presented in table 12. The table shows that the key results continue to hold when the current account variable is the average current account over the past five years.

\section{Conclusion}

This paper sets out to ask: is credit growth itself the cause of a banking crisis, or is it the combination of credit growth and external deficits? Does the source of credit matter?

To answer this question we estimate the marginal effect of an increase in the private sector debt-to-GDP ratio on the probability of a banking crisis. There is a long literature suggesting that an increase in debt increases the probability of a crisis. Similarly there is a long literature suggesting that an increasing current account deficit increases the probability 
of a crisis. This paper shows that the marginal effect of increasing debt on the probability of a crisis is highly dependent on an economy's external position. When the current account is in surplus or in balance, and thus these rising debt levels are financed at home, the marginal effect of an increase in debt is rather small; a 10 percentage point increase in the debt-toGDP ratio increases the probability of a crisis by less than 1 percentage point. However, when the economy is running a sizable current account deficit, implying that any increase in the debt ratio is financed through foreign borrowing, this marginal effect can be large. When a country has a current account deficit of $10 \%$ of GDP (which is similar to the value in the Eurozone periphery on the eve of the recent crisis) a 10 percentage point increase in the debt ratio leads to a 5 percentage point increase in the probability of a crisis. 


\section{References}

Ai, Chunrong, and Edward C. Norton, 2003, Interaction terms in logit and probit models, Economic Letters 80, 123-129.

Aizenman, Joshua, and Ilan Noy, 2013, Macroeconomic adjustment and the history of crises in open economies, Journal of International Money and Finance 38, 41-58.

Arteta, Carlos, and Barry Eichengreen, 2002, Banking Crises in Emerging Markets: Presumptions and Evidence, in: M. Blejer, M. Skreb, eds, Financial Policies in Emerging Markets(MIT Press, Cambridge, MA).

Barrell, Ray, E.P. Davis, D. Karim, and I. Liadze, 2010, Does the current account balance help to predict banking crises in OECD countries?, mimeo.

Borio, Claudio, and Philip Lowe, 2002, Asset prices, financial and monetary stability: exploring the nexus, BIS Working Paper no. 114.

Calomiris, Charles W., and Stephen H. Haber, 2014, Fragile by Design: The Political Origins of Banking Crises and Scarce Credit (Princeton University Press, Priceton and Oxford).

Chinn, Menzie D, and Kenneth M Kletzer, 1999, International capital inflows, domestic financial intermediation and financial crises under imperfect information, in: Federal Reserve Bank of San Francisco Proceedings number Sep.

Copelovitch, Mark S., and David Andrew Singer, 2012, Tipping the (im)balance: Capital inflows, financial market structure, and banking crises, mimeo.

Demirgüç-Kunt, Asli, and Enrica Detragiache, 1998, The determinants of banking crises in developed and developing countries, IMF Staff Papers.

2005, Cross-country empirical studies of systemic banking distress: A survey, IMF Working Paper 05/96.

Eichengreen, Barry, and Andrew K Rose, 2004, Staying afloat when the wind shifts: External factors and emerging-market banking crises, in: Guillermo Calvo Maurice Obstfeld and Rudiger Dornbusch, eds, Money, Capital Mobility, and Trade: Essays in Honor of Robert A. Mundell) 171-205.

Goldschmidt, Raimund W., 1933, The Changing Structure of American Banking (George Routledge and Sons, London).

Hume, Michael, and Andrew Sentance, 2009, The global credit boom: Challenges for macroeconomics and policy, Journal of International Money and Finance 28, 1426-1461.

Ilzetzki, Ethan, Carmen M. Reinhart, and Vincent R. Reinhart, 2008, Exchange rate arrangements entering the 21st century: Which anchor will hold?, mimeo.

Jayaratne, Jith, and Philip E. Strahan, 1996, The finance-growth nexus: evidence from bank branch deregulation, Quarterly Journal of Economics 111, 639-668. 
Jordà, Òscar, Moritz HP. Schularick, and Alan M. Taylor, 2011a, Financial crises, credit booms, and external imbalances: 140 years of lessons, IMF Economic Review.

2011b, When credit bites back: Leverage, business cycles, and crises, NBER Working Paper No. 17621.

2013, Sovereigns versus banks: Credit, crises, and consequences, NBER Working Paper No. 19506.

Kaminsky, Graciela L., and Carmen M. Reinhart, 1999, The twin crises: The causes of banking and balance-of-payments problems, American Economic Review 89(3), 473500 .

King, Mervyn, 1994, Debt deflation: Theory and evidence, European Economic Review $38,419-445$.

King, Robert G., and Ross Levine, 1993, Finance and growth: Schumpeter might be right, Quarterly Journal of Economics 108, 717-737.

Laeven, Luc, and Fabián Valencia, 2013, Systematic banking crises database, IMF Economic Review 61, 225-270.

Loayza, Norman, and Romain Ranciere, 2005, Financial development, financial fragility, and growth, IMF Working Paper 05/170.

Mack, Adrienne, and Enrique Martínez-García, 2011, A cross-country quarterly database of real house prices: A methodological note, Federal Reserve Bank of Dallas, Globalization and Monetary Policy Institute Working Paper No. 99.

Magud, Nicloas E., Carmen M. Reinhart, and Esteban R. Vesperoni, 2011, Capital inflows, exchange rate flexibility, and credit booms, NBER Working Paper No. 17670.

McKinnon, Ronald I., and Huw Pill, 1996, Credible liberalizations and international capital flows: The overborrowing syndrome, in: Takatoshi Ito, Anne O. Krueger, eds, Financial Deregulation and Integration in East Asia, NBER-EASE Volume 5) 7-50.

Mendoza, Enrique G., and Macro E. Terrones, 2008, An anatomy of credit booms: Evidence from macro aggregates and firm level data, Paper presented at the Financial Cycles, Liquidity, and Securitization Conference Hosted by the International Monetary Fund.

2012, An anatomy of credit booms and their demise, NBER Working Paper no. 18379.

Mian, Atif, and Amir Sufi, 2009, Household leverage and the recession of 2007 to 2009, Presented at the 10th Jacques Polak Annual Research Conference.

Rajan, Raghuram G., and Luigi Zingales, 1998, Financial dependence and growth, American Economic Review 88, 559-586.

Reinhart, Carmen M., and Kenneth S. Rogoff, 2009, This Time is Different: Eight Centuries of Financial Folly (Princeton University Press, Priceton, N.J.). 
_ 2011, From financial crash to debt crisis, American Economic Review 101, 1676-1706.

Reinhart, Carmen M., and Vincent R. Reinhart, 2008, Capital flow bonanzas: An encompassing view of the past and present, NBER Working Paper No. 14321.

Schularick, Moritz HP., and Alan M. Taylor, 2012, Credit booms gone bust: Monetary policy, leverage cycles, and financial crises, 1870Ü2008, American Economic Review 102(2), 1029-1061. 


\section{Appendix}

\subsection{Country and Time Coverage}

The full list of countries that are used in the estimation as well as the year that the data sample begins in each country is presented in table 13. In addition, the countries listed with

bold lettering are included in the subset of developed countries used in the estimation in table 10. 
Table 1: Means and standard deviations of the variables in the model Mean S.D. across countries S.D. across time

\begin{tabular}{cccc}
\hline \hline$p_{i t}$ & 4.45 & 20.35 & 13.87 \\
$\Delta C_{i t}(1)$ & 3.27 & 18.58 & 19.48 \\
$\Delta C_{i t}(2)$ & 0.14 & 5.37 & 5.22 \\
$\Delta C_{i t}(3)$ & 0.83 & 17.10 & 17.43 \\
$\Delta C_{i t}(4)$ & 12.84 & 17.10 & 18.27 \\
$C A_{i t}$ & 0.14 & 3.47 & 4.39 \\
$O G_{i t}$ & 0.00 & 2.79 & 2.38 \\
$\pi_{i t}$ & 24.25 & 54.44 & 74.37 \\
$X R_{i t}$ & 0.49 & 0.29 & 0.48 \\
\hline \hline
\end{tabular}

Notes: All values are in percentage terms. (1) represents the measure of excess credit growth where excess growth is defined as the growth in the credit-to-GDP ratio in excess of what can be explained by growth in per capita GDP. (2) represents the measure of excess credit growth where excess growth is defined as the growth in the credit-to-GDP ratio in excess of the HP trend of credit growth. (3) represents the measure of excess credit growth where excess growth is defined as the growth in the credit-to-GDP ratio in excess of its linear trend. (4) represents the measure

of excess credit growth that is simply actual credit growth and ignores any trend.

Table 2: Unconditional correlations between the variables in the model.

\begin{tabular}{|c|c|c|c|c|c|c|c|c|c|}
\hline$p_{i t}$ & $\begin{array}{l}p_{i t} \\
1.00\end{array}$ & $\Delta C_{i t}(1)$ & $\bar{c}_{\Delta C_{i t}(2)}$ & $\Delta C_{i t}(3)$ & $\Delta C_{i t}(4)$ & $C A_{i t}$ & $O G_{i t}$ & $\pi_{i t}$ & $\overline{X R_{i t}}$ \\
\hline$\Delta C_{i t}(1)$ & 0.16 & 1.00 & & & & & & & \\
\hline$\Delta C_{i t}(2)$ & 0.08 & 0.37 & 1.00 & & & & & & \\
\hline$\Delta C_{i t}$ & 0.17 & 0.89 & 0.45 & 1.00 & & & & & \\
\hline$\Delta C_{i t}$ & 0.17 & 0.93 & 0.40 & 0.95 & 1.00 & & & & \\
\hline$C A_{i t}$ & -0.11 & -0.18 & -0.03 & -0.25 & -0.24 & 1.00 & & & \\
\hline$O G_{i t}$ & 0.17 & 0.05 & 0.06 & 0.26 & 0.25 & -0.15 & 1.00 & & \\
\hline$\pi_{i t}$ & 0.06 & -0.10 & 0.03 & -0.07 & -0.13 & -0.09 & -0.05 & 1.00 & \\
\hline$X R_{i t}$ & 0.04 & 0.20 & -0.06 & 0.13 & 0.22 & -0.12 & 0.09 & -0.15 & 1.00 \\
\hline
\end{tabular}

Notes: All values are in percentage terms. (1) represents the measure of excess credit growth where excess growth is defined as the growth in the credit-to-GDP ratio in excess of what can be explained by growth in per capita GDP. (2) represents the measure of excess credit growth where excess growth is defined as the growth in the credit-to-GDP ratio in excess of the HP trend of credit growth. (3) represents the measure of excess credit growth where excess growth is defined as the growth in the credit-to-GDP ratio in excess of its linear trend. (4) represents the measure of excess credit growth that is simply actual credit growth and ignores any trend. 

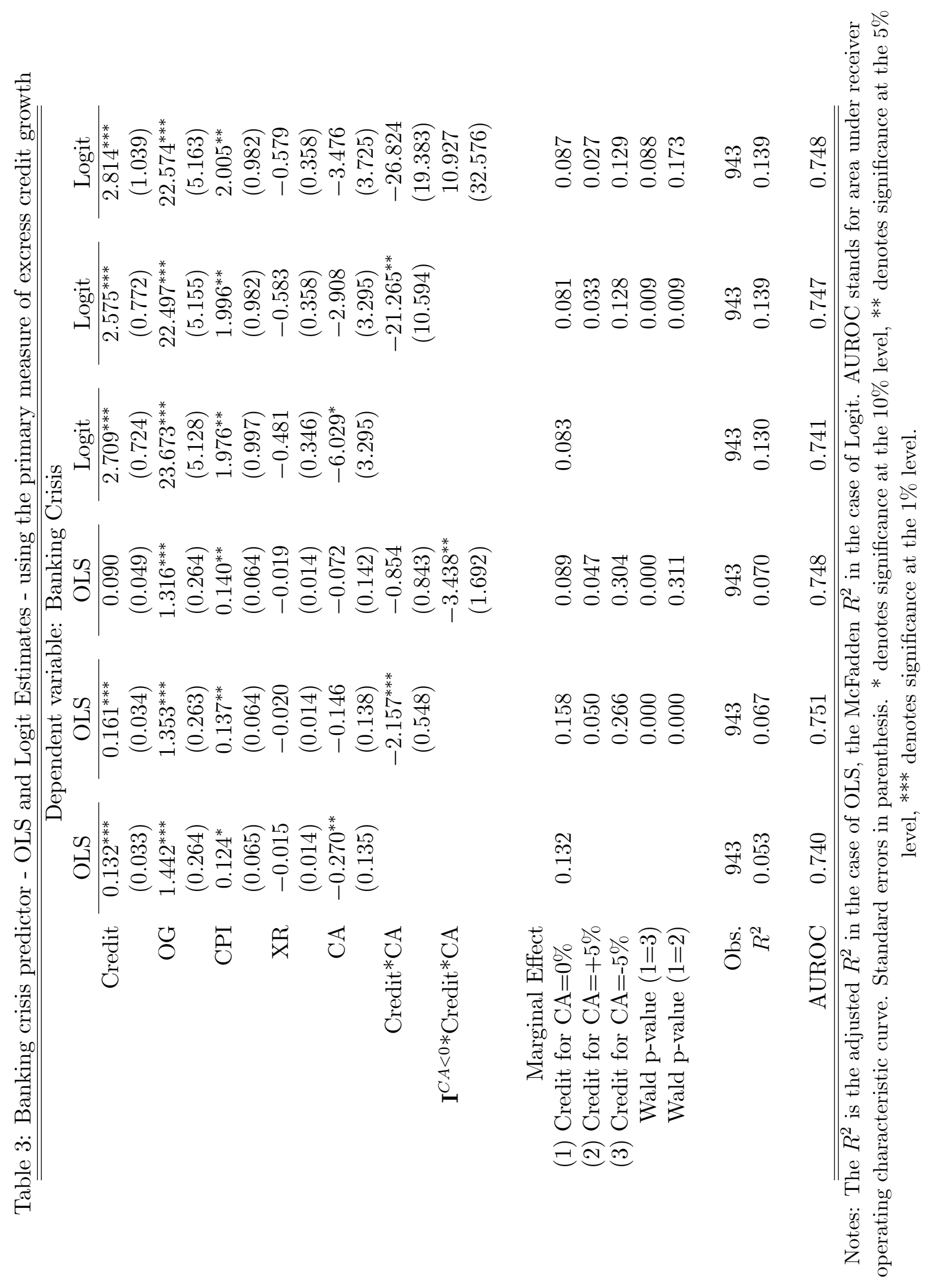


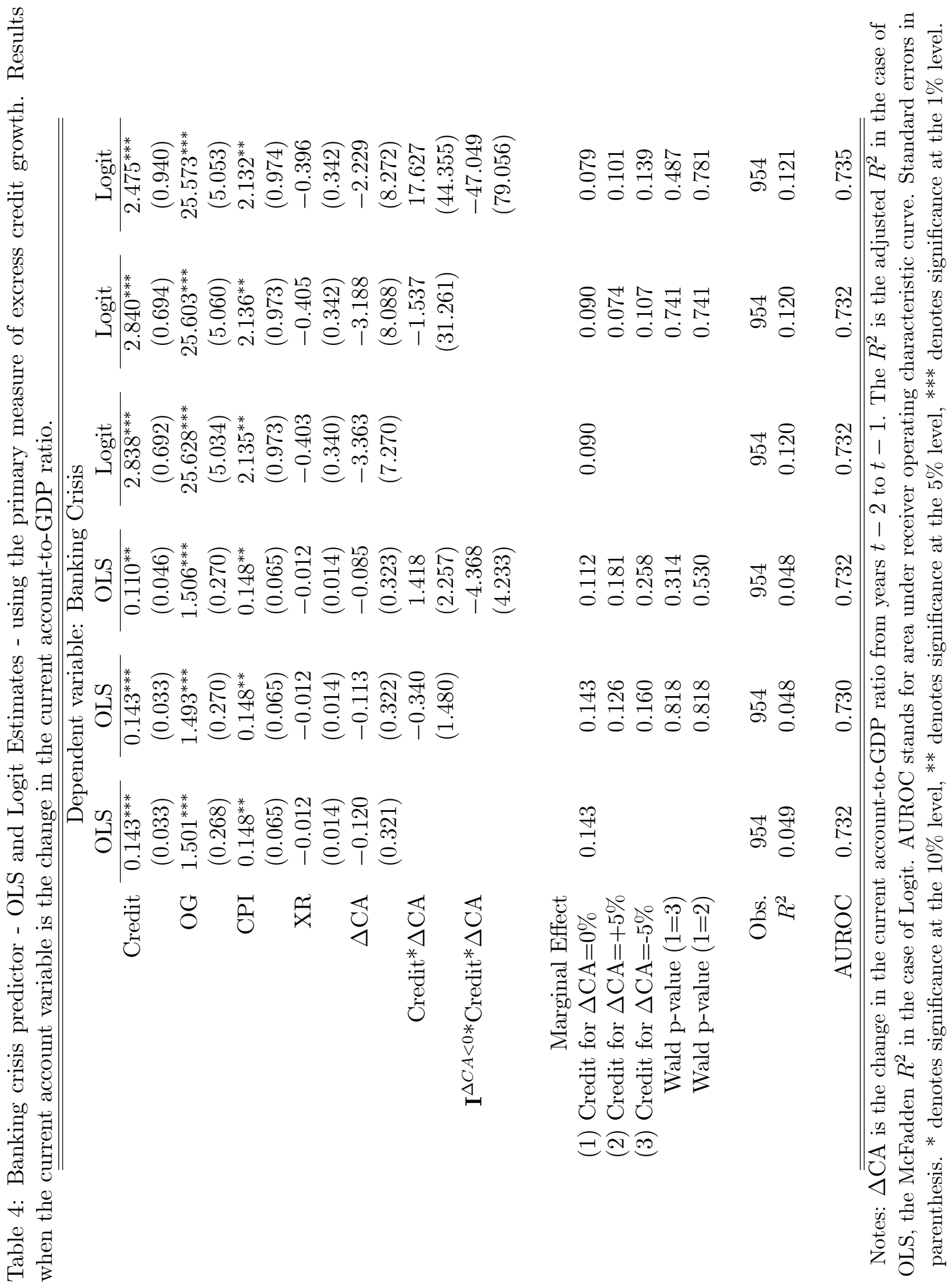


Table 5: The probabilities of a banking crisis in 2008 for some selected European countries.

\begin{tabular}{ccccccc}
\hline \hline Country & $\Delta C_{i t}$ & $C A$ & $P_{1}($ Crisis $)$ & $P_{2}$ (Crisis) & $P_{3}($ Crisis $)$ & Crisis? \\
\hline$E S$ & 74.40 & -9.62 & 48.72 & 72.88 & 70.94 & Yes \\
$P T$ & 48.54 & -12.64 & 18.66 & 28.30 & 27.31 & Yes \\
$G R$ & 40.26 & -14.92 & 53.20 & 66.97 & 65.28 & Yes \\
$I E$ & 143.04 & -5.64 & 80.66 & 92.81 & 92.61 & Yes \\
$H U$ & 68.43 & -7.32 & 38.94 & 54.02 & 53.09 & Yes \\
$F I$ & 27.74 & 2.61 & 12.49 & 9.62 & 9.55 & No \\
$N O$ & 33.98 & 15.95 & 5.57 & 3.23 & 2.85 & No \\
$S E$ & 68.24 & 9.04 & 16.81 & 6.21 & 5.50 & No \\
\hline
\end{tabular}

Notes: $\overline{\text { Probabilities are calculated with a logit model, excess credit growth is measured as actual }}$ credit growth minus a fitted value of credit growth based on growth in per capita income.

$P_{1}$ (Crisis) is the estimated probabilities of a banking crisis in the model without the interaction between credit growth and the current account, $P_{2}$ (Crisis) is the probability of a banking crisis in the model with the interaction term, $P_{3}$ (Crisis) is the probability of a banking crisis in the model with the interaction term that distinguishes between a current account deficit and surplus. 


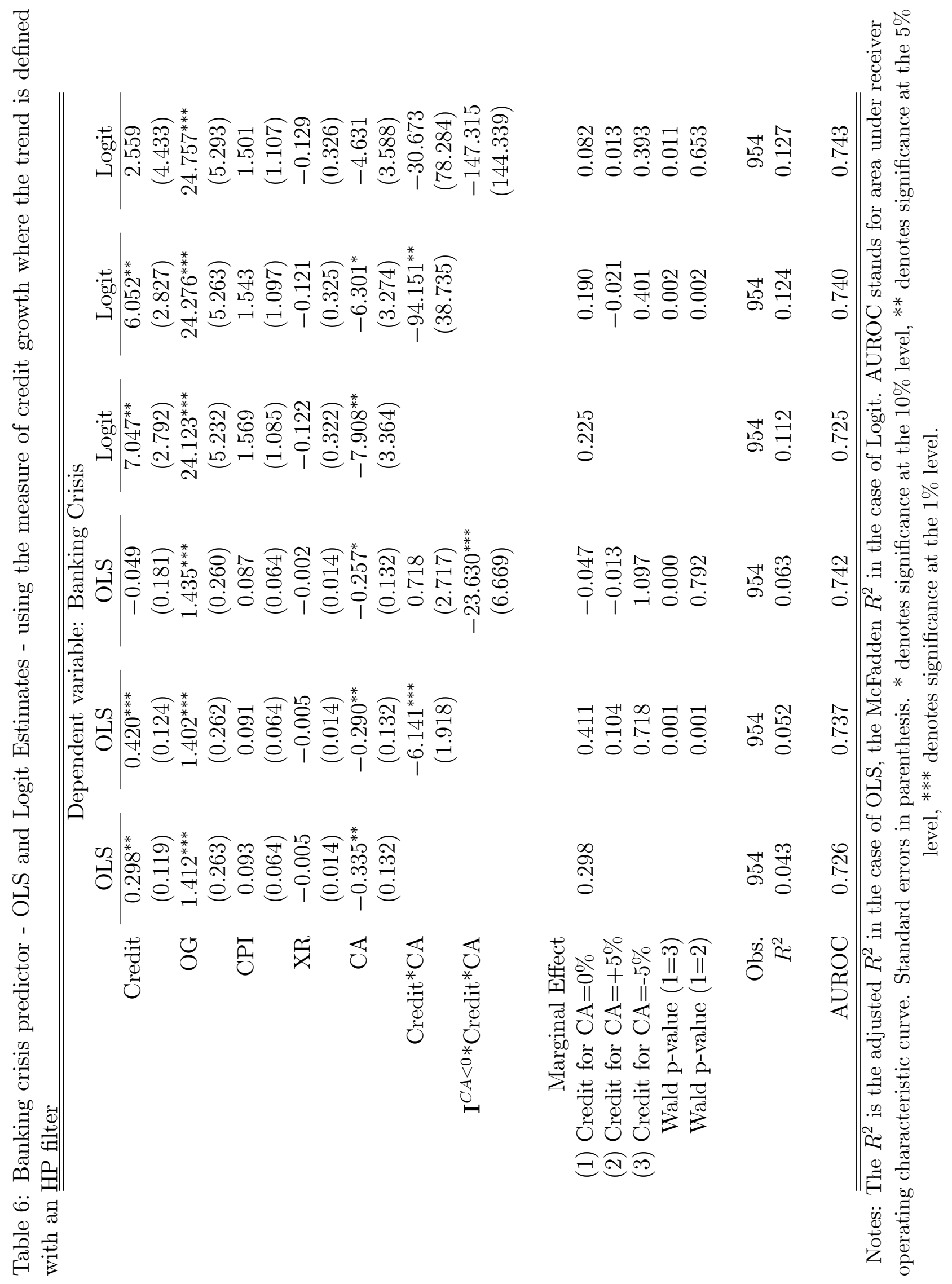




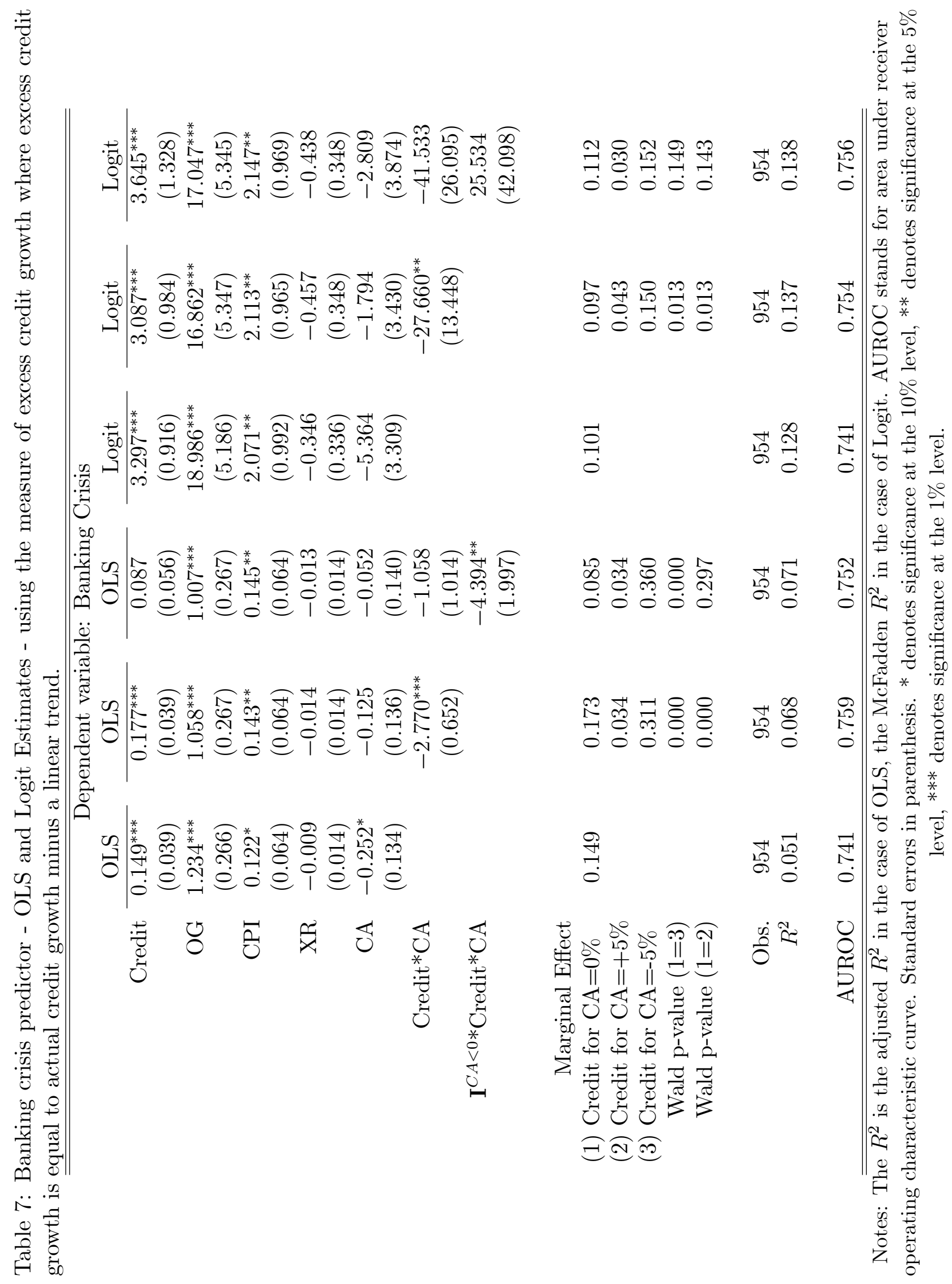




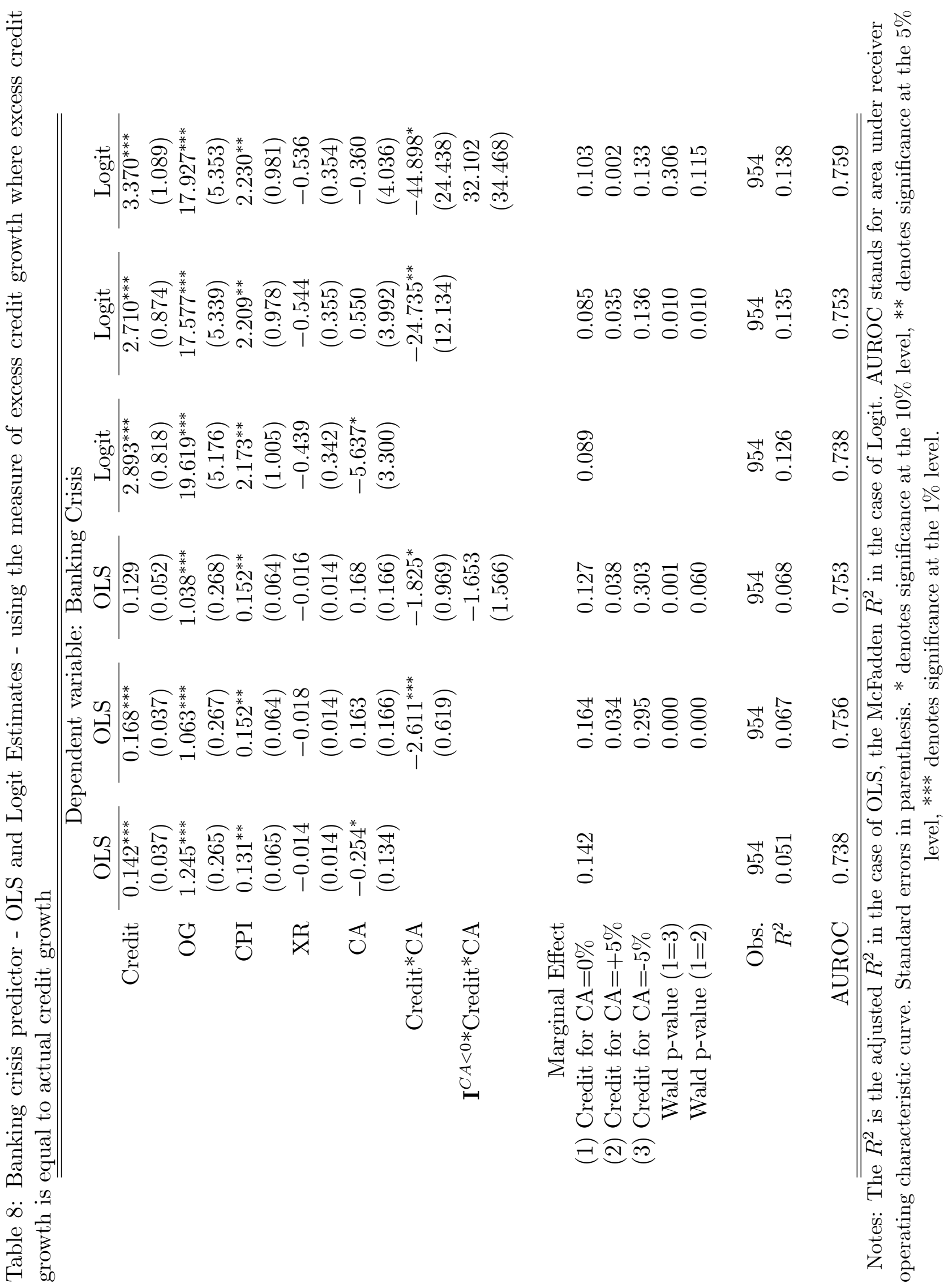




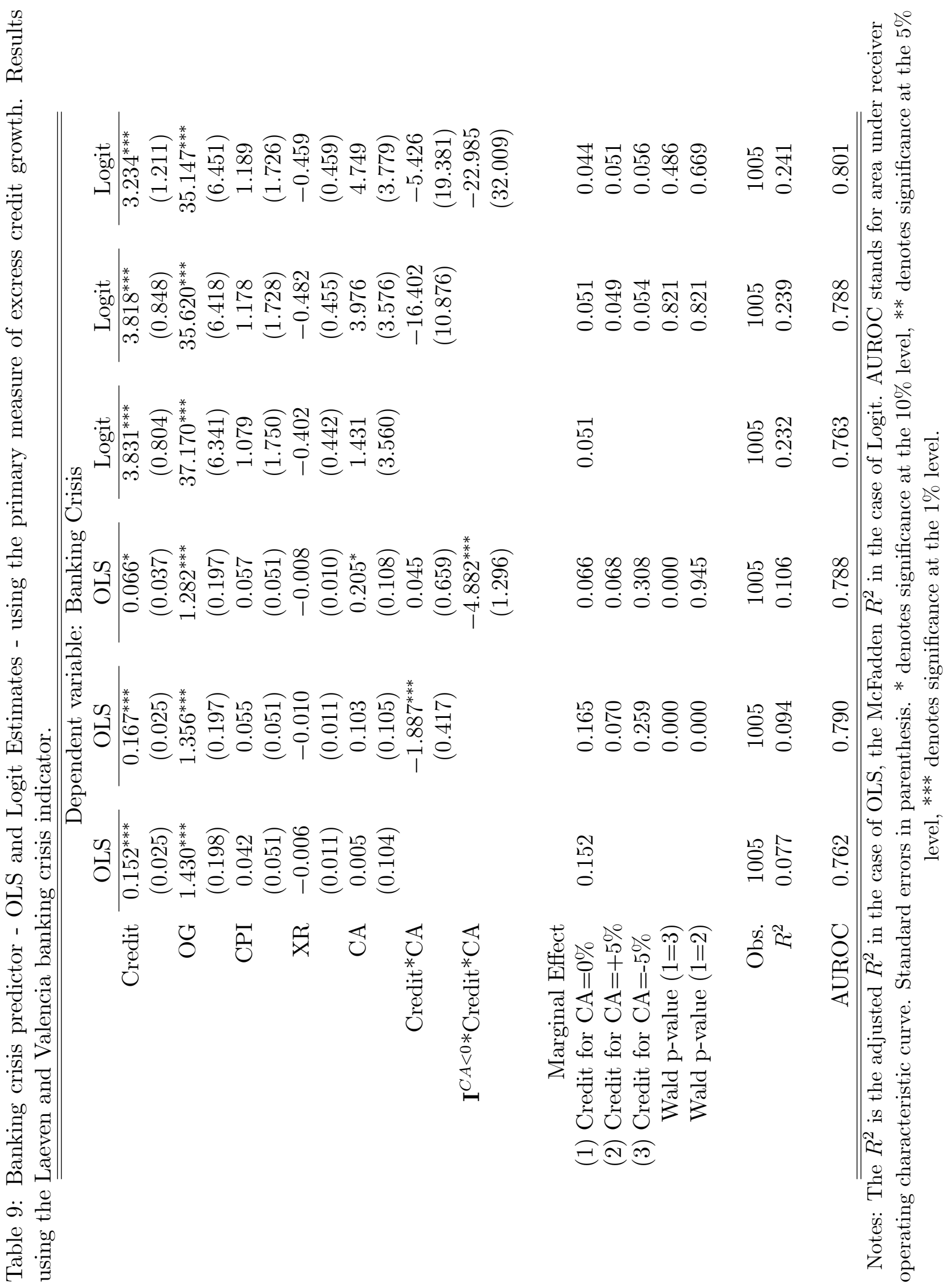




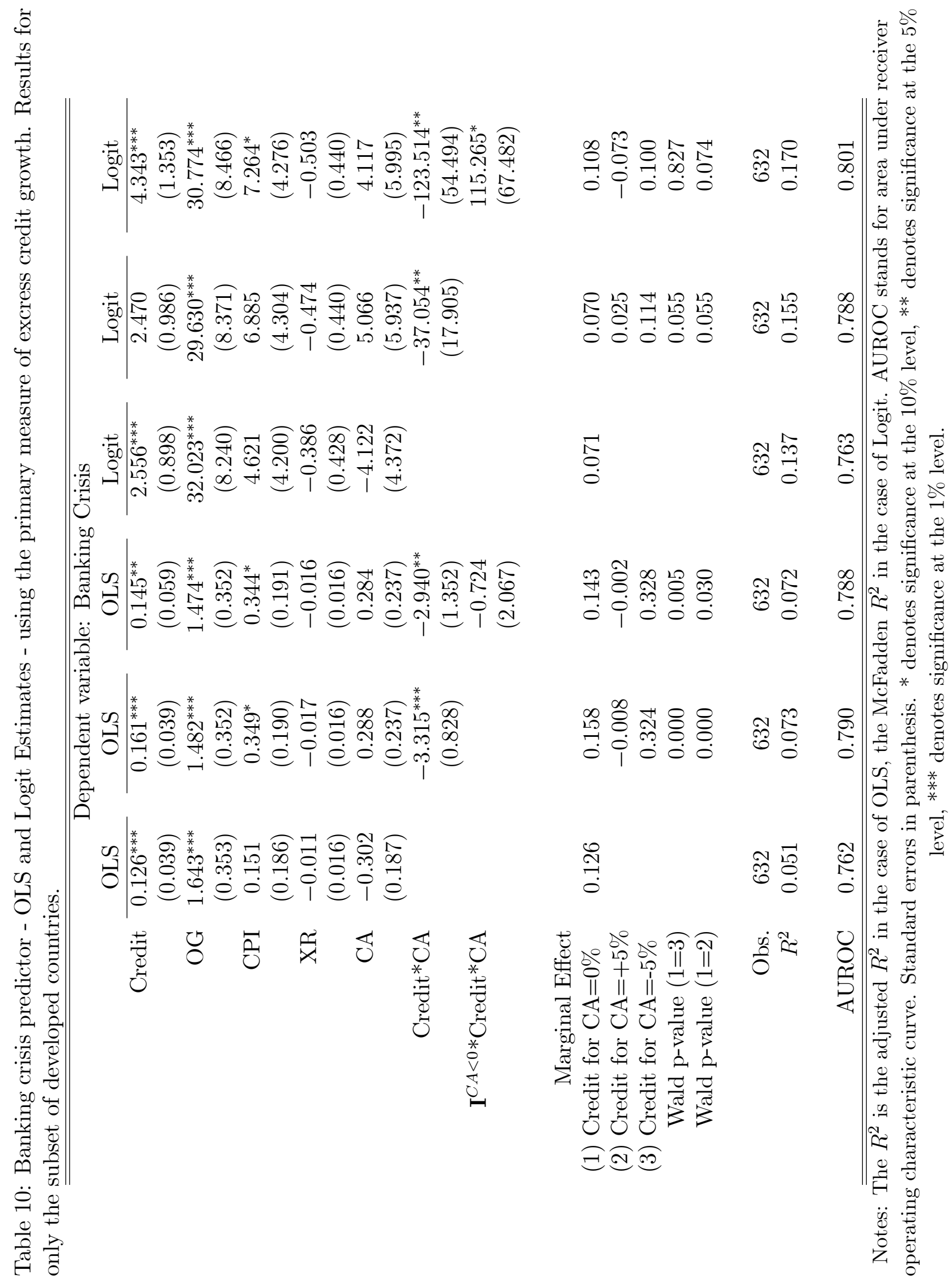




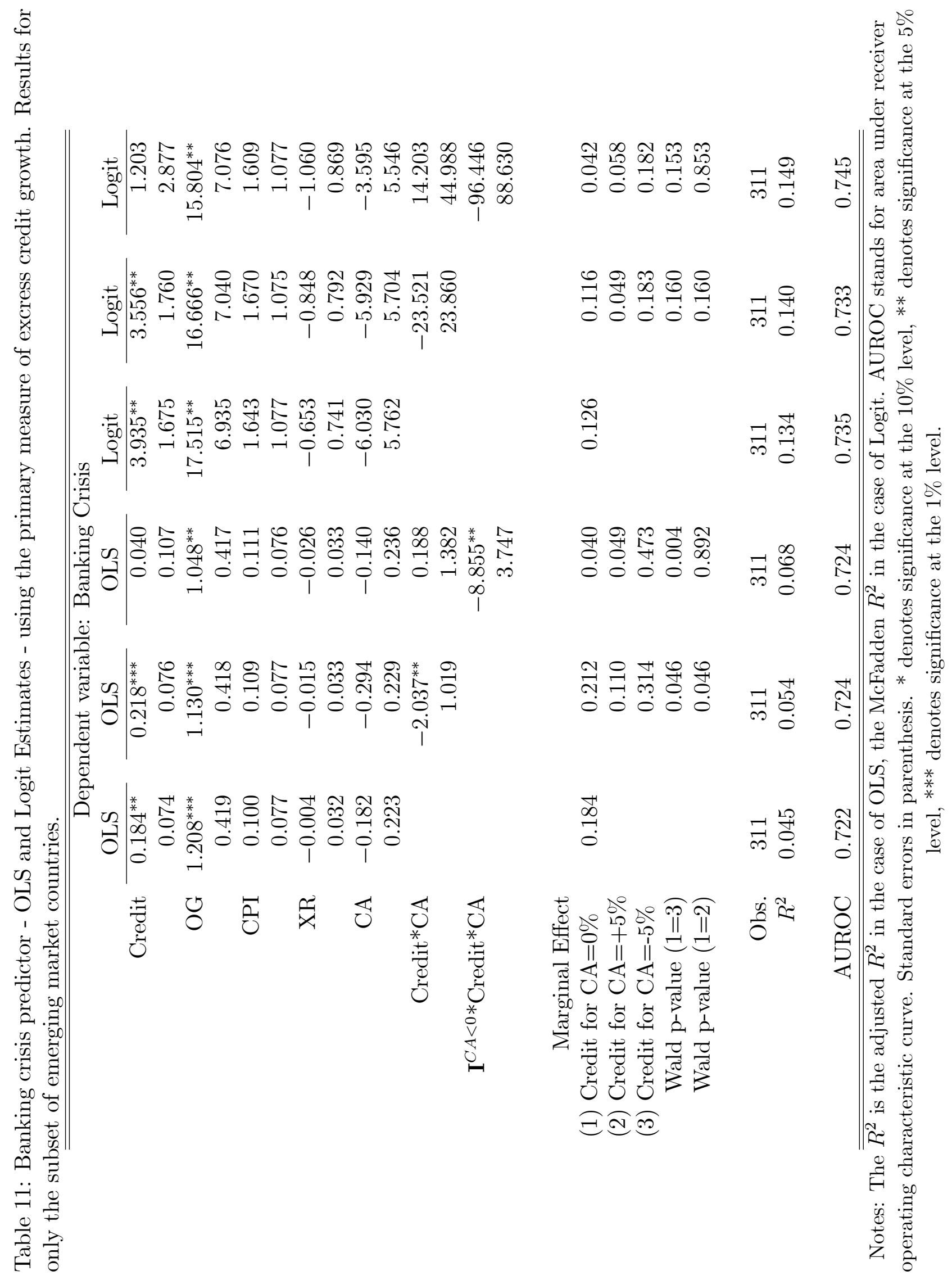




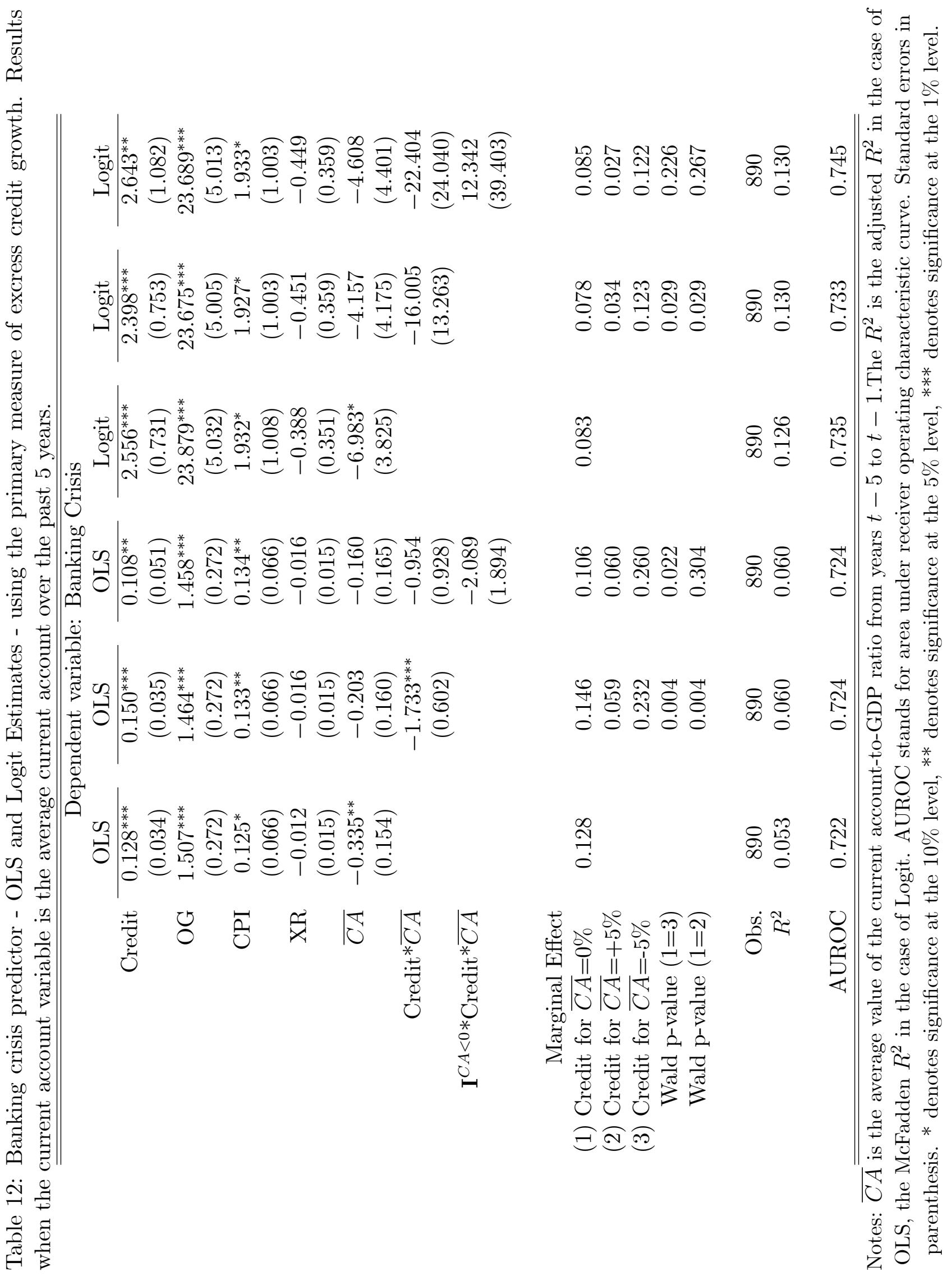


Table 13: The countries used in the estimations and the year that the sample begins in each country.

\begin{tabular}{ccc}
\hline \hline Country & & Year sample begins \\
\cline { 1 - 1 } \cline { 3 - 3 } Argentina & 2002 \\
Austria & & 1975 \\
Australia & & 1975 \\
Belgium & & 1979 \\
Brazil & & 1999 \\
Canada & & 1975 \\
Switzerland & & 1980 \\
China & & 1990 \\
Germany & & 1975 \\
Denmark & & 1984 \\
Spain & & 1979 \\
Finland & & 1979 \\
France & & 1977 \\
Greece & & 1984 \\
Hungary & & 2000 \\
Indonesia & & 1988 \\
Ireland & & 1990 \\
India & & 1975 \\
Italy & & 1975 \\
Japan & & 1975 \\
South Korea & & 1979 \\
Mexico & & 1985 \\
Malaysia & & 1984 \\
The Netherlands & 1975 \\
Norway & 1979 \\
Poland & 1998 \\
Portugal & 1979 \\
Russia & & 2000 \\
Sweden & & 1979 \\
Singapore & & 2002 \\
Thailand & & 1985 \\
Turkey & & 1992 \\
United Kingdom & & 1975 \\
United States & & 1975 \\
South Africa & & 1975 \\
\hline \hline & & \\
\hline & & \\
\hline & & \\
\hline
\end{tabular}




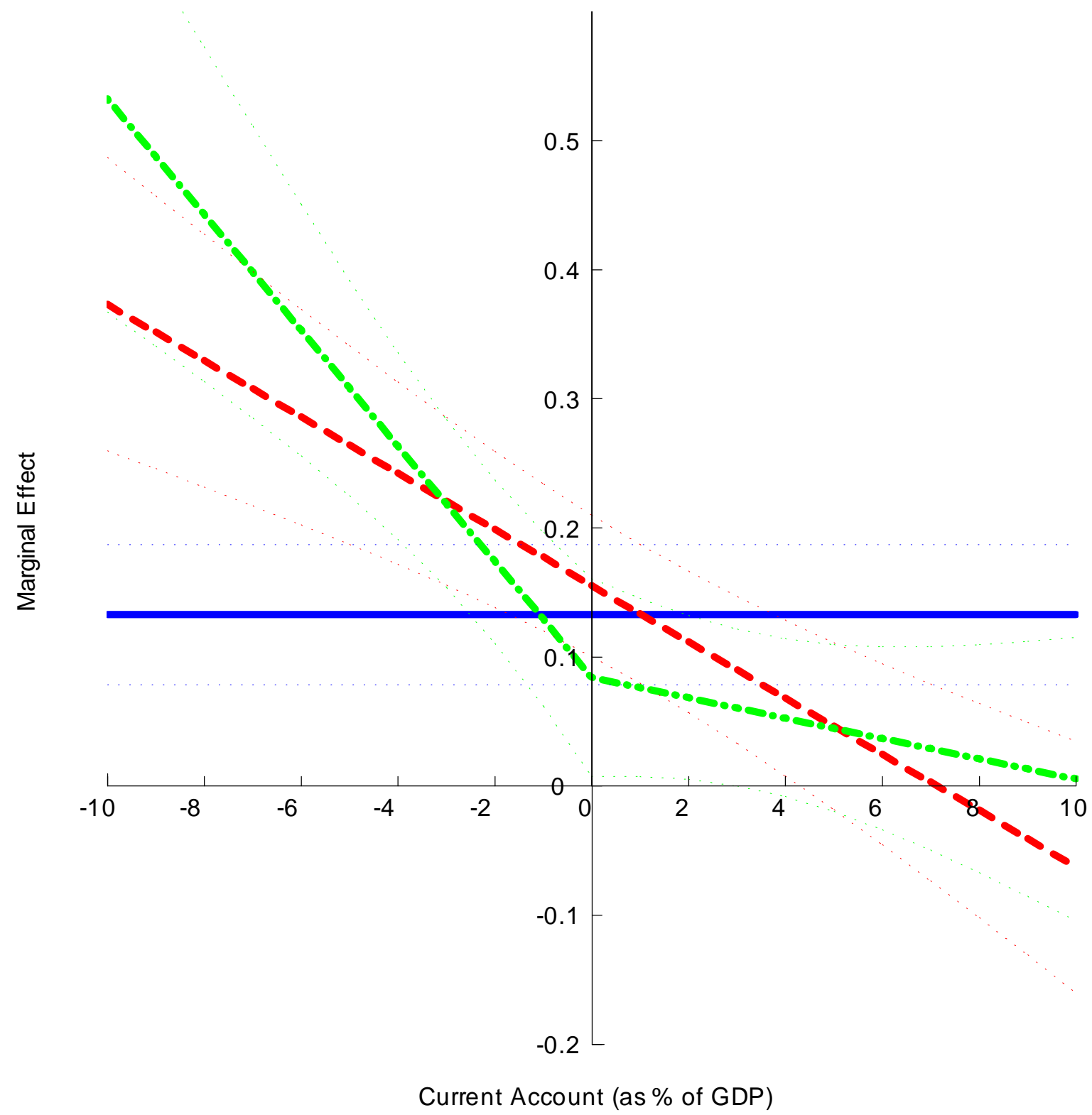

Figure 1: The marginal effect of credit growth on the probability of a banking crisis. Blue solid line is the marginal effect from the model with no interaction term. The red dashed line is from the model with an interaction term, the green dash-dot line is from the model with an interaction term that distinguishes between a current account surplus or deficit. The faint dotted lines represent $90 \%$ confidence bands. 


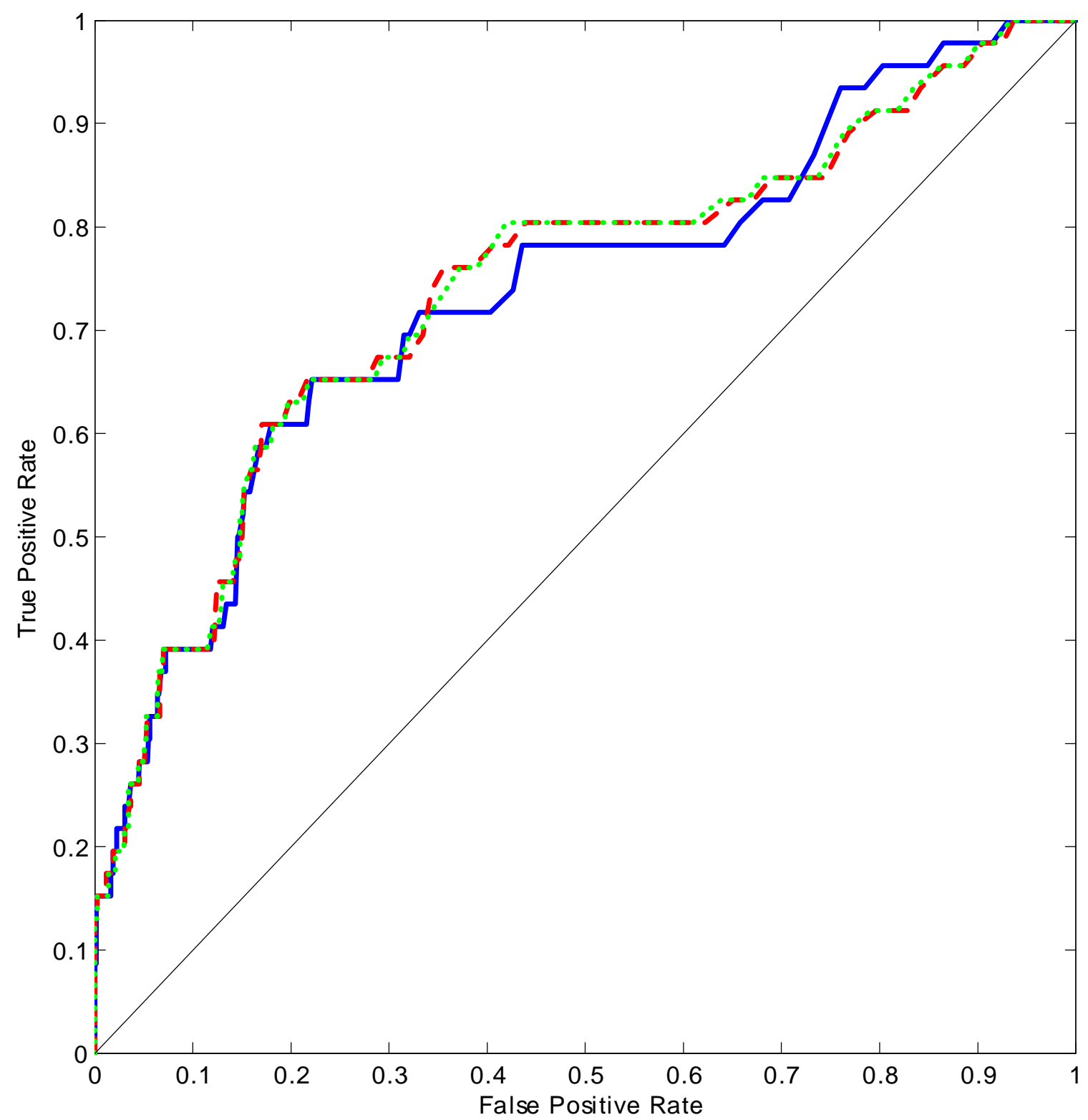

Figure 2: Receiver operating characteristic curves for each of our three logit models. Blue solid line is from the model with no interaction term. The red dashed line is from the model with an interaction term, the green dotted line is from the model with an interaction term that distinguishes between a current account surplus or deficit. 